\title{
APPLICATION OF THE BETA COEFFICIENT IN THE MARKET OF DIRECT RESIDENTIAL REAL ESTATE INVESTMENTS
}

\author{
Rafał Wolski, Ph.D. \\ Department of Economics of Industry and Capital Markets \\ Faculty of Economics and Sociology \\ University of Lodz \\ e-mail:rwolski@uni.lodz.pl
}

\begin{abstract}
The beta coefficient is one of the most popular indices used in contemporary finances. Despite the fact that there are justified doubts connected with its application, it is currently difficult to imagine a situation in which the cost of capital would be calculated without the use of the CAPM model. Thus, an attempt at answering the question whether and to what degree beta may be used in the real estate market constitutes an interesting problem. This is because on the one hand, the formal structure suggests that beta should not be used for assets which are not included in the benchmark but, on the other hand, such a benchmark should, at least theoretically, contain all market assets. Therefore, a decision was made to have a closer look at this issue, with the analysis of the possibility of using the beta coefficient in the residential real estate market set as the objective. Using the database of prices in the direct real estate investment created by the NBP, a comparison was conducted with regard to features of undertaken investments on the basis of an analysis of systematic risk calculated using selected indices available on the Polish market.
\end{abstract}

Key words: beta coefficient, systematic risk, real estate market, CAPM.

JEL Classification: G11, G12, R20.

Citation: Wolski R., 2014, Application of beta coefficient in the market of direct residential real estate investments, Real Estate Management and Valuation, vol. 22, no. 2, pp. 13-21.

DOI: $10.2478 /$ remav-2014-0013.

\section{Introduction}

Investors with real estate in their portfolios are often not aware or even have no knowledge of the risk involved in their investments. It is not uncommon for them to estimate the level of risk on the basis of their own experience or opinions, which may lead to incorrect assessment. This problem is discussed, among others, by KUCHARSKA-STASIAK (2006a, p.118) in her paper. In this context, the measurement of risk with the use of the beta coefficient gains additional importance. As there are problems connected with risk assessment, the methodology of such estimations has been neglected. In the measurement using the sensitivity measure - the beta coefficient, the basic problem is the fact that the CAPM model is not used in the real estate market. The theory related to this model clearly indicates the rate of return for the entire market as the benchmark for calculating the level of systematic risk. This is a problem, because although an appropriate index may be found for the equity market, or generally for the market of enterprises, which for Poland will be the broadest market index - WIG, such an index may fail to work for real estate. This is mainly because the index does not include any assets related to direct real estate investments, which may result in an incorrect estimation of the level of risk and, in consequence, making wrong investment decisions. 


\section{Risk in the real estate market}

The capital asset pricing model, as a relatively simple structure both from the theoretical point of view and where its application is concerned, creates a temptation to apply it blindly, even where the conditions restricting its use have not been fulfilled. This raises questions concerning the justifiability of applying the beta coefficient in the real estate market.

Risk in the real estate market may be determined using measures of variability and sensitivity (KUCHARSKA - STASIAK 2006b, p. 113). Measures of variability include standard deviation (CZAJA, LIGAS 2010, p.8), or semi-standard deviation. These measures allow the level of total risk to be determined. However, theoreticians indicate that risk may be partly reduced through the diversification of the investment portfolio. In such a case risk shall constitute the total of diversifiable risk, subject to reduction in the diversification process, and non-diversifiable risk, referred to as systematic risk. This risk, also referred to as market risk and connected with changes in the market (SITEK 2012, p.185), is calculated using the measure of sensitivity. It is examined by comparing the response of the investment portfolio to changes taking place in the market. At least several authors described the essence of those correlations by introducing the CAPM (TREYNOR 1961, 1999, SHARPE 1964, LITNER 1965, MOSSIN 1966, JENSEN 1968). The beta coefficient was adopted as the measure of systematic risk, which is at the same time the measure of sensitivity:

$$
\beta=\operatorname{cov}(\operatorname{Ri}, \operatorname{Rr}) / \operatorname{var}(\operatorname{Rr})
$$

where:

$\operatorname{cov}(\mathrm{Ri}, \mathrm{Rr}) \quad$ - covariance between rates of return from the investment portfolio Ri and the entire $\operatorname{var}(\mathrm{Rr}) \quad$ market $\mathrm{Rr}$,
$\quad$ - variance of the market rate of return.

\section{Capital Asset Pricing Model}

Contemporary finance theoreticians recognize that an investor is characterized by risk aversion. This means that an investor is sensitive to the level of risk related to the specific asset category. The source of this approach is portfolio analysis, the essence of which is the optimum combination of risk and profit. When an investment is made, the level of risk determines the future expected rate of return. The higher the risk, the higher the required rate of return. In the case of portfolio diversification and risk measurement using the beta coefficient, this correlation takes the following form:

$$
\mathrm{Ri}=\mathrm{Rw}+\beta^{*}(\mathrm{Rr}-\mathrm{Rw})
$$

where:

$\mathrm{Ri}$

Rw - rate of return from investments devoid of risk (for example Treasury bonds),

$\beta$ - beta coefficient, sensitivity measure determining the systematic risk level,

$\mathrm{Rr} \quad-$ rate of return from the entire market,

(Rr-Rw) - market premium for risk.

The CAPM, however, has a number of limitations which can decide whether or not it can be applied. The assumptions on which the Capital Asset Pricing Model has been constructed are as follows:

- transactions in the market are always concluded without costs, there are no margins or commissions,

- assets are perfectly divisible, you can buy any part of them,

- investors do not pay personal income tax,

- there is perfect competition on the market and none of the investors have the possibility of influencing the price of assets at their own discretion,

- when shaping an optimum portfolio, investors follow only the criterion of the expected rate of return and the standard deviation of that rate,

- short selling is permitted on the market,

- investors may contract and grant loans in an unlimited amount, with the rate of return equal to the rate of return from risk-free assets,

- investors are characterized by homogenous predictions, which means that their expectations as to the rate of return, its variance and covariance between the rates of return from all assets are 
identical,

- all assets are subject to market trading.

The assumptions presented above are impossible to fulfill, even in such a liquid and transparent market as the capital market. Direct real estate investments entail additional limitations.

\section{The real estate market and its limitations}

Real estate is perceived in the contemporary economy as an alternative to investments in the capital market. The conviction that its correlation with the securities market is low causes this market to be regarded as a source of instruments facilitating the effective diversification of the investment portfolio. However, direct real estate investments entail limitations not known to other types of assets. The most important of these include (KUCHARSKA - STASIAK, 2006b, p. 17-19):

- indivisibility,

- capital intensity,

- constant location,

- diversity,

- low liquidity.

Indivisibility means that it is impossible to buy any selected part of the real estate. In the case of residential real estate, this comes down to having to purchase the entire apartment. This feature is also expressed in the lack of possibility of withdrawing part of the invested capital. Thus, the second feature, capital intensity, is revealed. Although one can buy part of an enterprise by disbursing capital only on individual shares, in the case of purchasing an apartment, its entire value must be paid. This, depending on a number of factors, usually constitutes a significant amount.

Constant location means that real estate is strongly connected with a specific place, both in the physical and economic meaning. Constant location also implies a strong correlation with the local real estate market. Diversity is the consequence of significant differentiation, not only of real estate as a whole, but even between its parts - for example apartments in a single block. The lack of standardization rules out mass trading, similar to that of securities. It is necessary to apply an individual approach and perform a valuation of each real estate.

The situation is similar in the case of low liquidity, which is the consequence of all features presented so far. The sale of real estate usually requires time, for example to distribute information about the offer, and incurring additional costs related to the transaction. Any attempts to speed up the transaction usually imply the need to reduce the price below its market level.

These features are in open conflict with the assumptions of the CAPM. Nevertheless, despite all the limitations which the beta coefficient entails, it has found practical application. The lack of alternatives in the measurement of systematic risk to some extent forces the use of solutions from the capital market in the market of direct real estate investments as well. Examples of such application may be found in literature. However, despite the copying of the formula, certain assumptions have been modified. These changes are described further on in the article. All modifications were aimed at adapting the research method to the conditions and possibilities of the Polish economic reality.

\section{Implementation of the beta coefficient in the direct real estate market}

Examples of the practical application of systematic risk measures in direct real estate investment markets can be found in literature. It has been noticed that investors may be unaware of the level of risk which real estate investments entail. However, the knowledge of the level of risk, as theory indicates, may be very important from the point of view of acquiring an adequate rate of return on an investment. This is because it may turn out that, having estimated risk incorrectly, the investor will pay over the odds for the investment. BREIDENBACH, MUELLEr, and SCHULTE (2006) transformed the CAPM in such a way so that it may be successfully applied to calculate meaningful betas. In consequence, they noted the need to create a model which will enable the investors to correctly estimate the cost of capital for investments in the private real estate market. Thus, scientists have undertaken efforts to determine the required rate of return on individual investors' investments in the private real estate market. It was agreed that the CAPM may be applied in the real estate market on condition that an appropriate index encompassing real estate is used as a benchmark.

VOICU and SEILER'S paper (2013), in turn, addressed the problem of the diversification of the level of systematic risk in real estate depending on its geographical location within the United States. This 
diversification allows for the creation of an investment portfolio, which is more effective than the analysis of the real estate market index would indicate. One of the observations which seems particularly interesting is the use of the real estate market index for the calculation of the beta coefficient. It should be considered whether a classically calculated beta coefficient may be applied in a market for which rates of return are not included in the benchmark used for the calculation of systematic risk. VOICU and SEILER (2013) decided that the real estate market index would be a more adequate index rather than the S\&P500 index, most frequently used in the USA. This is a bold statement, going against the theory describing the capital asset pricing model. As stated among others by SHARPE (1964), market equilibrium in the CAPM is determined using the rate of return from all assets listed in the given market. In this context, both the S\&P500 index and the real estate market index will not constitute benchmarks with a sufficient range of described investments. So it may be true that a different rate of return should indeed be used for the real estate market than for the equity market. However, this causes a serious problem in Poland. First and foremost, there is no index available which would satisfactorily describe the changes of prices in all markets, not just in the capital market.

The problems addressed in the cited articles inspired the author to assess whether the beta coefficient based on the wide market index describes the risk related to investing directly in the residential real estate market sufficiently well under Polish conditions. It is possible that, similarly to the case of American research, it would be better to use an index related to the real estate market. A research hypothesis was constructed that the hedonic index calculated by the NBP provides the best description of risk involved in investing in residential property. The construction of a model which would allow the quality of the calculated beta coefficients to be assessed has been adopted as the objective of the article. In order to verify the hypothesis, the author conducted research in which the following indices were successively taken on as the benchmark: WIG, WIG Developers and the hedonic index of the residential real estate market calculated by the NBP.

\section{CAPM test in the residential market in Poland}

A test based on the test performed in the American capital market by BLACK, JENSEN and SCHOLES (1972) was conducted in order to test the adequacy of the beta coefficient as a risk measure. However, certain modifications were made in the test methodology, adapting the research to the possibilities and specific nature of the Polish market.

\subsection{Data}

A database of house prices in 16 Polish cities published by the National Bank of Poland was used for the research. The database includes hedonic indices of house prices on the secondary real estate market from the $4^{\text {th }}$ quarter of 2006 to the $3^{\text {rd }}$ quarter of 2013 in individual cities and for all of the cities combined. The cities included in the database are: Białystok, Bydgoszcz, Trójmiasto (Gdańsk, Sopot, Gdynia as one metropolitan area), Katowice, Kielce, Kraków (Cracow), Lublin, Łodź, Olsztyn, Opole, Poznań, Rzeszow, Szczecin, Warszawa (Warsaw), Wrocław, and Zielona Góra. The rates of return from the WIG and WIG Developers stock exchange indices were calculated in the same way for those quarters. Information about the value of indices was obtained from the Warsaw Stock Exchange. The WIG Developers index has been listed since 18 June 2007, thus the research conducted with the use of this index was based on a shorter time series. A database of risk-free rates, calculated as the average return on ten-year bonds, was created for each of the quarters. The data were taken from the database provided by the Ministry of Finance.

\subsection{Methodology}

Using the hedonic indices for housing in all 16 cities, quarterly percentage changes in these indices were calculated. A similar process was used for the WIG, WIG Developers and NBP house price indices. Next, beta coefficients were calculated for each of the indices, including market indices and the NBP hedonic index. It was assumed that the period on the basis of which betas were calculated had to include fifteen observations. Thus, 14 beta coefficient observations were obtained for the WIG index and NBP indices. Due to the absence of earlier listings, only 11 observations were obtained in the case of the WIG Developers index. Historic risk-free rate determined on the basis of the return on ten-year Treasury Bonds was matched to each of the observations. Next, the data were sorted according to the increasing value of the beta coefficient. Thus sorted observations were organized into 
eight investment portfolios, with two investments with increasing beta coefficients included in each. For each of the quarters, eight separate portfolios were created, each time matching the composition of the portfolio to the value of the beta coefficient. In consequence, the first portfolio included two cities with the lowest betas, and the last - two cities with the highest beta coefficients. Next, the mean was calculated from those portfolios, both for the rate of return and the beta coefficient. As a result, eight portfolios with mean beta and rate of return values were obtained. Regression analysis was conducted on these data, checking whether the portfolios with the lowest coefficients indeed had the lowest rates of return and, analogically, whether the rate of return from the portfolio increases in line with the increase of the coefficient of the given portfolio.

\subsection{Research results}

The effect of the research conducted was obtaining 14 beta coefficients in terms of the WIG and NBP indices, and 11 beta coefficients for the WIG Developers index. Superficial analysis does not provide any possibilities for assessing the quality of the calculated systematic risk levels. One may suspect, however, that the benchmark used is important, as betas take on very different values, sometimes even describing extreme responses to market changes. Table 1 presents the level of systematic risk in the last, i.e. third, quarter of 2013 covered by the research.

Table 1

Beta coefficients in Q3 2013 in the market of direct residential real estate investments

\begin{tabular}{lrrr}
\hline & beta - & beta - WIG & \multicolumn{2}{c}{ beta - NBP } \\
Q3 2013 & WIG & Developers & index \\
\hline Białystok & .117 & .084 & .079 \\
\hline Bydgoszcz & .074 & .016 & .023 \\
\hline Tricity & .045 & .001 & -.019 \\
\hline Katowice & .298 & .115 & .009 \\
\hline Kielce & .017 & .025 & .056 \\
\hline Kraków & .174 & .140 & .162 \\
\hline Lublin & -.228 & -.079 & .167 \\
\hline Eódź & .144 & .089 & .160 \\
\hline Olsztyn & -.023 & -.024 & .021 \\
\hline Opole & -.748 & -.452 & .221 \\
\hline Poznań & -.013 & .119 & .104 \\
\hline Rzeszów & .075 & .053 & .139 \\
\hline Szczecin & .018 & .066 & -.005 \\
\hline Warszawa & .000 & -.055 & .099 \\
\hline Wrocław & .042 & .069 & .163 \\
\hline Zielona Góra & .137 & .217 & .359 \\
\hline
\end{tabular}

Source: Own study.

The risk of investments in the housing market in Lublin can serve as an example of extreme results. The sensitivity to changes of the WIG index becomes negative at -0.228 , sensitivity to changes of WIG Developers is -0.079, whereas systematic risk calculated for the NBP index is positive at 0.167.

Table 2 presents the dynamic changes of the beta coefficient calculated in relation to the NBP hedonic index. In the presented results, attention should be drawn to the considerable variability of beta. Generally, investors cannot be certain that by investing in housing in a given city they will retain a similar level of systematic risk for the duration of the investment. For example, investments in the housing market in Łódź and Katowice may be considered. Whereas in the second quarter of 2010 investments in Łódź were characterized by risk at around - 0.755 , the risk in Katowice amounted to 0.15. However, in the fourth quarter of 2011, the beta coefficient for Katowice was 2.189, whereas for 
Łódź: 0.273. Meanwhile, in the last examined quarter, systematic risk for an investment in Katowice came to 0.009 , and for the Łódź investment: 0.160 .

Table 2

Beta coefficient (benchmark: NBP index) in subsequent quarters

\begin{tabular}{|c|c|c|c|c|c|c|c|c|c|c|c|c|c|c|}
\hline $\begin{array}{l}\text { subsequent } \\
\text { quarters/ } \\
\text { city }\end{array}$ & $\begin{array}{l}\text { II } \\
2010 \\
\end{array}$ & $\begin{array}{l}\text { III } \\
2010 \\
\end{array}$ & $\begin{array}{l}\text { IV } \\
2010 \\
\end{array}$ & $\begin{array}{l}\text { I } \\
2011 \\
\end{array}$ & $\begin{array}{l}\text { II } \\
2011 \\
\end{array}$ & $\begin{array}{l}\text { III } \\
2011 \\
\end{array}$ & $\begin{array}{l}\text { IV } \\
2011 \\
\end{array}$ & $\begin{array}{l}\text { I } \\
2012 \\
\end{array}$ & $\begin{array}{l}\text { II } \\
2012 \\
\end{array}$ & $\begin{array}{l}\text { III } \\
2012 \\
\end{array}$ & $\begin{array}{l}\text { IV } \\
2012 \\
\end{array}$ & $\begin{array}{l}\text { I } \\
2013 \\
\end{array}$ & $\begin{array}{l}\text { II } \\
2013 \\
\end{array}$ & $\begin{array}{l}\text { III } \\
2013 \\
\end{array}$ \\
\hline Białystok & -.372 & .233 & .319 & .220 & .088 & .157 & .131 & .231 & .493 & .174 & 299 & .115 & .070 & .079 \\
\hline Bydgoszcz & -.258 & $\begin{array}{r}- \\
.506 \\
\end{array}$ & .321 & .290 & $\begin{array}{r}- \\
.081 \\
\end{array}$ & .133 & -.013 & $\begin{array}{r}- \\
\\
\end{array}$ & .013 & .073 & .052 & .005 & .070 & .023 \\
\hline Tricity & -.316 & .019 & .389 & .282 & .324 & .069 & .299 & .191 & .304 & .297 & .307 & .157 & .099 & .019 \\
\hline Katowice & -.015 & $\begin{array}{r}- \\
.308\end{array}$ & .641 & .514 & .338 & 1.522 & 2.189 & .139 & .461 & .038 & .010 & .127 & .079 & .009 \\
\hline Kielce & -.167 & $\begin{array}{r}- \\
.047 \\
\end{array}$ & .457 & .353 & .048 & .305 & .161 & .055 & .298 & .207 & .194 & .228 & .113 & .056 \\
\hline Kraków & -.291 & .101 & .004 & $\begin{array}{r}- \\
.133 \\
\end{array}$ & $\begin{array}{r}- \\
.075\end{array}$ & -.034 & .150 & $\begin{array}{r}- \\
.041\end{array}$ & .644 & .479 & .217 & .366 & .210 & .162 \\
\hline Lublin & .009 & $\begin{array}{r}- \\
.095\end{array}$ & .496 & .422 & .318 & .074 & .199 & .138 & .146 & .206 & .315 & .255 & .073 & .167 \\
\hline Łódź & -.755 &. & .417 & .336 & .127 & .107 & .273 & .441 & .664 & .158 & .229 & .253 & .177 & .160 \\
\hline Olsztyn & -.188 & .159 & .269 & .158 & .156 & -.060 & -.242 & $\begin{array}{r}- \\
.070\end{array}$ & .075 & .043 & .135 & .119 & .043 & .021 \\
\hline Opole & -.350 & . & .367 & .352 & .009 & .018 & .363 & .445 & .275 & .986 & .500 & .064 & .176 & .221 \\
\hline Poznań & -.209 & .096 & .335 & .206 & .133 & .257 & .041 & .172 & .394 & .532 & .155 & .538 & .169 & .104 \\
\hline Rzeszów & -.218 & .083 & .466 & .408 & .291 & -.024 & .257 & .288 & .326 & .165 & .196 & .217 & .147 & .139 \\
\hline Szczecin & -.206 & . & .359 & .344 & .064 & .110 & .303 & .241 & $\begin{array}{r}- \\
.128 \\
\end{array}$ & .054 & .085 & .153 & .028 & .005 \\
\hline Warszawa & -.440 & .109 & .211 & .171 & $\begin{array}{r}- \\
.005 \\
\end{array}$ & .015 & .055 & .190 & .118 & .143 & .176 & .132 & .180 & .099 \\
\hline Wrocław & -.102 & - & .077 & .024 &. & .009 & 162 & . 111 & .442 & .437 & .320 & .379 & 195 & .163 \\
\hline $\begin{array}{l}\text { Zielona } \\
\text { Góra }\end{array}$ & .038 & .353 & .383 & .295 & .018 & -.033 & .181 & .186 & .444 & .583 & .591 & .408 & .224 & .359 \\
\hline
\end{tabular}

Source: Own study.

Table 3 presents the result of transformations conducted in order to perform the test. The strategy adopted showed a higher level of risk in the direct real estate investment using the NBP index as the benchmark than in the case of WIG and WIG Developers indices. In the first case, portfolio risk was between -0.136 and 0.517 , whereas in the case of WIG, the spread was much lower, ranging from 0.228 to 0.088 . In the case of WIG Developers, the spread was even lower, between -0.162 and 0.137.

Table 3

Investment portfolios, rates of return and betas, cross-sectional data

\begin{tabular}{|c|c|c|c|c|c|c|}
\hline & $\begin{array}{l}\text { additional } \\
\text { mean } \mathrm{R}\end{array}$ & $\begin{array}{l}\text { mean } \\
\text { beta for } \\
\text { WIG }\end{array}$ & $\begin{array}{l}\text { additional } \\
\text { mean } \mathrm{R}\end{array}$ & $\begin{array}{l}\text { mean beta for } \\
\text { WIG } \\
\text { Developers }\end{array}$ & $\begin{array}{l}\text { additional } \\
\text { mean R }\end{array}$ & $\begin{array}{l}\text { mean beta } \\
\text { for NBP } \\
\text { index }\end{array}$ \\
\hline portfolio 1 & -.052 & -.228 & -.054 & -.162 & -.037 & -.136 \\
\hline portfolio 2 & -.054 & -.027 & -.050 & -.031 & -.054 & .005 \\
\hline
\end{tabular}




\begin{tabular}{lcccccc}
\hline portfolio 3 & -.065 & -.002 & -.054 & -.012 & -.052 & .072 \\
\hline portfolio 4 & -.052 & .021 & -.053 & .000 & -.048 & .120 \\
\hline portfolio 5 & -.063 & .040 & -.062 & .012 & -.046 & .161 \\
\hline portfolio 6 & -.051 & .061 & -.062 & .023 & -.067 & .215 \\
\hline portfolio 7 & -.062 & .088 & -.056 & .043 & -.072 & .285 \\
\hline portfolio 8 & -.047 & .148 & -.057 & .137 & -.069 & .517 \\
\hline
\end{tabular}

Source: Own study.

An analysis of cross-sectional linear regression has been conducted on data from table 3. The values of model parameters have been presented in table 4 .

Results of cross-sectional regression analysis for the studied indices

\begin{tabular}{lrrrrrr}
\hline \multicolumn{1}{c}{ Model } & \multicolumn{2}{c}{$\begin{array}{c}\text { Unstandardized } \\
\text { coefficients }\end{array}$} & $\begin{array}{c}\text { Standard } \\
\text { error }\end{array}$ & \multicolumn{1}{c}{$\mathrm{t}$} & R-squared & $\begin{array}{c}\text { Pearson } \\
\text { correlation }\end{array}$ \\
\hline (Constant) & -.056 & .003 & $-21.441^{* *}$ & & \\
\hline $\begin{array}{l}\text { beta in relation to } \\
\text { WIG }\end{array}$ & -.001 & .025 & -.046 & .000 & -.019 \\
\hline (Constant) & -.056 & .002 & $-35.847^{* *}$ & & \\
\hline $\begin{array}{l}\text { beta in relation to } \\
\text { WIG Developers }\end{array}$ & -.017 & .020 & -.853 & .108 & -.329 \\
\hline (Constant) & -.047 & .004 & $-12.919^{* *}$ & & \\
\hline $\begin{array}{l}\text { beta in relation to } \\
\text { NBP index }\end{array}$ & -.052 & .015 & $-3.399^{*}$ & .658 & $-.811^{*}$ \\
\hline${ }^{*}$ significance at 0.05 & & & & & \\
${ }^{* *}$ significance at 0.01 & & & & &
\end{tabular}

Source: Own study.

Values of regression of the additional rate of return explained by beta - NBP index - attract attention in the obtained results. This beta explains changes of the dependent variable in a statistically significant manner. The correlation coefficient is strong at -0.811 , and is statistically significant at the confidence level of $95 \%$. The conducted analysis indicates the beta for the NBP index as the one which best describes the level of risk in the housing market in Poland. The distribution of real variables in relation to the linear model has been presented in fig. 1. The negative slant of the empirical SML line observed in the results may be quite puzzling. Such a situation takes place when the market does not cover the entire business cycle. Unfortunately, the data available do not allow an analysis based on a longer time series. Together with the development of the market and an increase in the available price data, the model should change in the direction indicated by theoreticians.

The research results are promising and provide hope that benchmarks which could be used to determine the level of systematic risk in the housing market in Poland have been found. However, it should be emphasized that the NBP hedonic index describes the changes of prices exclusively in the housing market. This means that it cannot be used to examine the entire spectrum of risk factors occurring in the economy, and the risk measures presented are not identical. The benchmark used conditions the application of beta. A beta which has been calculated in relation to other indices describes other market areas.

\section{Conclusions}

In the real estate market, investors may incorrectly estimate the level of risk accompanying their investments, thus making wrong investment choices. According to the conviction existing in contemporary finance, in a market which is in equilibrium, the investor will require a higher rate of return as risk increases. Thus, the incorrect assessment of the level of risk may be reflected in the composition of the investment portfolio. Risk may be measured using measures of variability and sensitivity. In the case of the second type, the problem of a benchmark exists as it is required to 
analyze variability. Research shows that the behavior of the beta coefficient - the measure of sensitivity - may cause serious concerns as to the correctness of the methodology applied, especially in the context of limitations imposed by the CAPM. Therefore, an idea was conceived to use a benchmark that is much better adapted to the real estate market than the broad market index usually applied in such cases (S\&P500 in the USA, or WIG in Poland).
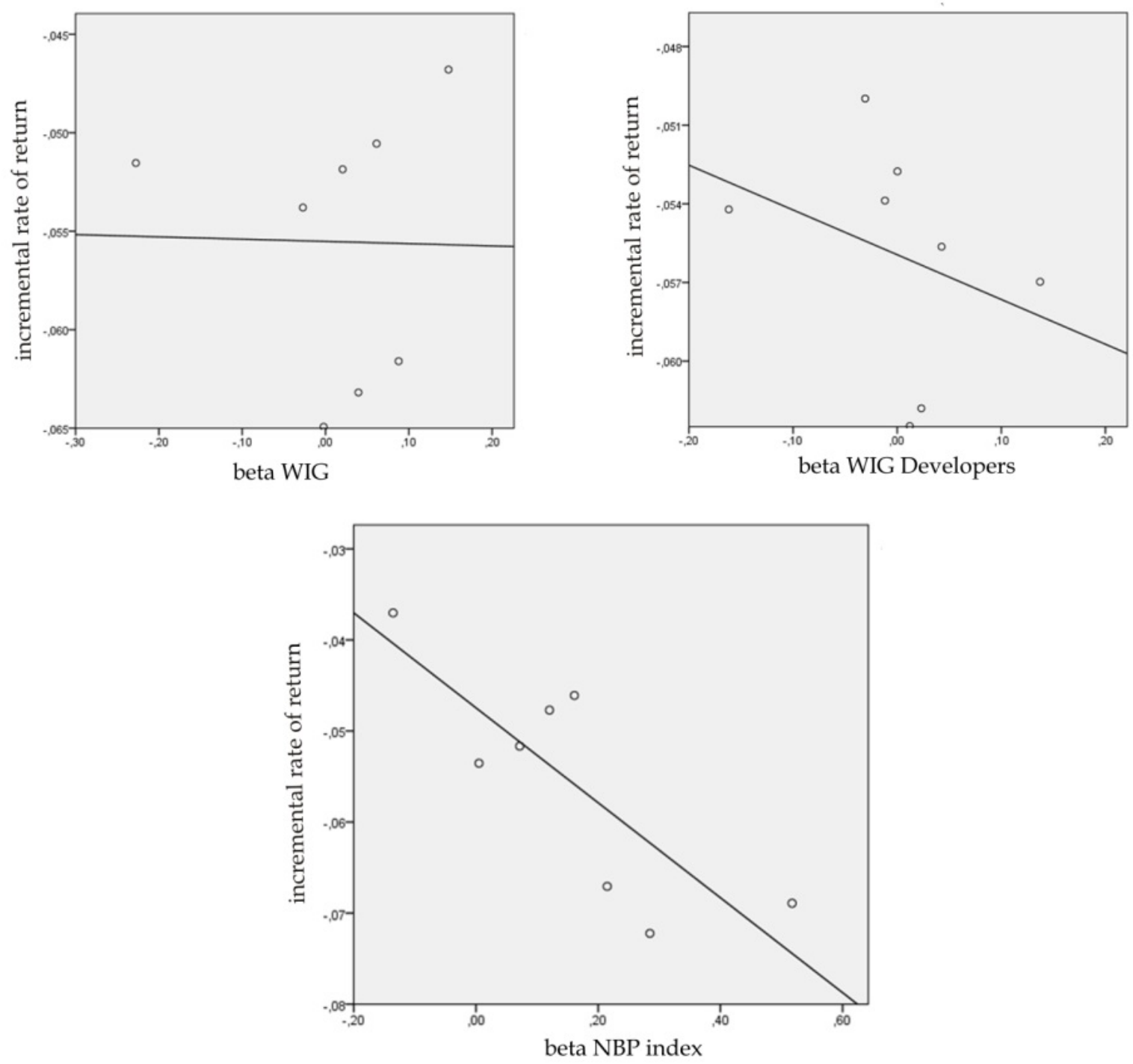

Fig. 1. Regression lines for subsequent analyzed beta coefficients. Source: own study.

Although certain indices which seem to fit into the real estate market analysis may be found in developed economies, there is no index in Poland which would describe the real estate market as a whole. However, the NBP established a database of housing real estate prices, together with the hedonic index of house prices throughout Poland. It was assumed that this index could be a benchmark for the measurement of the level of systematic risk in the housing investment market in Poland. In order to check this, a test was conducted for investment portfolios composed of housing investments in different cities and beta coefficients calculated in relation to three indices: WIG, WIG Developers and the NBP index. As a result of the conducted analysis, it was proven that the beta calculated in relation to the NBP index quite accurately describes the market equilibrium in the real estate market, and the correlation between the risk and profit reached a relatively high value at -0.811 , which is statistically significant at a level of 0.05 . Therefore, it may be assumed that thus calculated beta accurately describes the level of risk in the housing real estate market. It is, however, important to note that, because the benchmark does not contain other prices listed in the economy, the beta may only be used to compare the risk between investments in the housing market. For instance the 
comparison of betas for investments in housing in Łódź and for investments in mortgage bonds would not be reliable.

\section{References}

CZAJA, J., LiGAS, M., 2010, Zaawansowane metody analizy statystycznej rynku nieruchomości, (Advanced statistical analysis for real estate market reaserch), Studies and Materials of the Polish Real Estate Scientific Society (Towarzystwo Naukowe Nieruchomości), scientific editor: S. Źróbek, vol. 18, no. 1, Olsztyn, pp. 7-20.

KUCHARSKA - STASIAK, E., 2006a, Ryzyko inwestowania na rynku nieruchomości, (Investment risk on a real estate market), Studies and materials of the Polish Real Estate Scientific Society (Towarzystwo Naukowe Nieruchomości), scientific editor: S. Źróbek, vol. 14, no. 1, Olsztyn, pp. 109-122.

TREYNOR, J., 1961, Market Value, Time and Risk, nonpublished paper.

TreYNOR, J., 1999, Toward a Theory of Market Value of Risky Assets, paper 1962, published in: Asset Pricing and Portfolio Performance, red.: Korajczyk R.A., Risk Books, London, pp. 15-22.

SITEK, M., 2012, Analiza i zarządzanie ryzykiem inwestycyjnym na rynku nieruchomości, (Analysis and management of investment risk on real estate market), in: Przedsiębiorczość i Zarządzanie, Finansowe aspekty zarządzania organizacjami (Financial aspects of organisation management), scientific editor: M. Wypych, vol. XIII, no. 18, Wydawnictwo SAN, Łódź, pp. 181-192

SHARPE, W., 1964, Capital Asset Prices : A Theory of Market Equilibrium Under Condition of Risk, Journal of Finance, September, pp. 425-442.

LiTNER, J., 1965, Security Prices, Risk and Maximal Gains from Diversification, Journal of Finance, December, pp. 587-615.

Mossin, J., 1966, Equilibrium of Capital Asset Market, Econometrica, October, pp. 768-783.

JENSEN, M.C., 1968, The Performance of Mutual Funds in the Period 1945-1964, Journal of Finance, May, pp. 389-417.

VOICU, C., SEILER, M. J., 2013, Understanding Systematic Risk in Real Estate Markets, Journal Of Housing Research, 22(2), pp. 165-201.

KUCHARSKA - STASIAK, E., 2006b, Nieruchomość w gospodarce rynkowej, (Real estate in a market economy), PWN, Warszawa.

Black, F, Jensen M.C., Scholes M., 1972, The Capital Asset Pricing Model: Some Empirical Tests, in: Studies in the Theory of Capital Markets, Praeger, New York, pp. 79-124.

Breidenbach, M., Mueller, G. R., Schulte, K., 2006, Determining Real Estate Betas for Markets and Property Types to Set Better Investment Hurdle Rates, Journal Of Real Estate Portfolio Management, 12(1), pp. 73-80. 